\title{
MARIA HELENA SOUZA PATTO
}

Homenageada

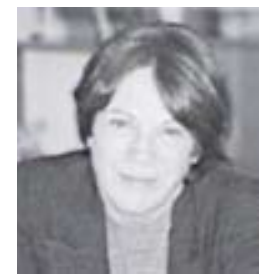

Especialista em Psicologia escolar, Maria Helena Souza Patto nasceu na cidade de Taubaté, no Vale do Paraíba, em São Paulo. Na fazenda onde morava, energia elétrica não havia. Mas isso não impediu que a mãe lesse para os filhos à noite e desenvolvesse neles o gosto pela leitura. Alfabetizada pela matriarca, Maria Helena mudou-se para São Paulo. No antigo primário, sentiu-se incomodada com o que encontrou. Lá percebeu as dificuldades de escolarização que sofriam a maioria das crianças e que, mais tarde, seriam o objeto das produções científicas da futura Doutora.

A escolha pela Psicologia aconteceu quando foi prestar o vestibular. Incentivada pela mãe, que queria vê-la médica psiquiátrica (e, com isso, romper o destino das mulheres daquela geração) e desinteressada em ciências exatas (conseqüência dos maus professores que teve no ginásio), Maria Helena formou-se em Psicologia em 1965. Cinco anos mais tarde, tornou-se Mestra, e 10 anos depois, Doutora pela Universidade de São Paulo (USP). Professora titular da Universidade, ela é consultora ad-hoc do Conselho Nacional de Desenvolvimento Científico e Tecnológico (CNPq) e da Coordenação de Aperfeiçoamento de Pessoal de Nível Superior (CAPES).

Os estudos na área de fracasso escolar, Psicologia escolar e pobreza renderam-lhe 17 títulos e prêmios por seus trabalhos, incluindo o Prêmio APEOESP 50 anos (Melhor livro sobre educação escolar - A produção do fracasso escolar: histórias de submissão e rebeldia). As pesquisas desenvolvidas pela Doutora referem-se ao chamado "fracasso escolar" das crianças pertencentes aos segmentos mais empobrecidos que habitam os grandes centros urbanos de uma sociedade capitalista dependente como a brasileira.

Para aprofundar o seu conhecimento, ela buscou em outras áreas, como a Filosofia, a história da Educação e do Brasil, os mecanismos necessários para entender os motivos que levam o País a ter altos índices de reprovação e evasão escolar entre as crianças. Ao longo desses quarenta e quatro anos de profissão, ela percebeu que a discussão girava em torno de duas questões fundamentais: o preconceito racial e social e as relações entre ciência e ideologia. "Se dei alguma contribuição, foi ter posto em questão as explicações oficiais das dificuldades de escolarização que assolam a maioria das crianças das classes populares, em um país tão desigual e que sempre tratou a educação pública com enorme descaso. Exceto em momentos em que ela (a educação) se tornou importante para os interesses dos que dominam, como formadora de mão-de-obra ou como instituição de ideologização maciça", explicou Maria Helena.

Desde 1968, participou de 147 eventos na área de Psicologia e Educação. O último foi no Congresso Internacional sobre a Inclusão da Pessoa com Deficiência Visual Comunicação e Participação, promovido pela USP em julho de 2007, em São Paulo. Desde que se tornou doutora na área, orientou 33 teses de mestrado e doutorado. Atualmente orienta teses de doutorado e é diretora do Instituto de Psicologia da Universidade de São Paulo. 